\title{
Thực trạng sử dụng tri thức bản địa về các loài động thực vật trong chăm sóc sức khỏe của các tộc người thiểu số tại huyện Lạc Dương, tỉnh Lâm Đồng
}

\section{Indigenous knowledge of using herbal and animal products as medicinal treatments among ethnic minorities in Lac Duong district, Lam Dong province}

\author{
Lê Thị Ngọc Phúc ${ }^{1 *}$ \\ ${ }^{1}$ Trường Đại học Khoa học Xã hội và Nhân văn - Đại học Quốc Gia Thành phố Hồ Chí Minh, \\ Việt Nam
}

*Tác giả liên hệ, Email: phucle@hcmussh.edu.vn

THÔNG TIN

DOI: $10.46223 /$ HCMCOUJS.

soci.vi.14.1.460.2019

Ngày nhận: 01/01/2019

Ngày nhận lại: 03/04/2019

Duyệt đăng: 10/04/2019

Tì khóa:

Lạc Dương, động thực vật, tộc người thiểu số, tri thức bản địa

\section{TÓM TẮT}

Bài viết tập trung trình bày thực trạng sử dụng tri thức bản địa trong chăm sóc sức khỏe và các yếu tố tác động đến thực trạng sử dụng của các tộc người ở huyện Lạc Dương - nơi nằm trong vùng lõi của khu dự trữ sinh quyển Lang Biang. Nghiên cứu được thiết kế theo hướng định lượng và định tính. Tổng cộng có 308 thông tín viên tại huyện Lạc Dương tham gia vào cuộc nghiên cứu. Dữ liệu được thu thập dựa vào công cụ bảng hỏi cấu trúc và bảng gợi ý phỏng vấn sâu. Trong đó, bảng hỏi cấu trúc tập trung tìm hiểu những đặc điểm của thông tín viên, thực trạng sử dụng những loại động thực vật trong việc chăm sóc sức khỏe. Những lý giải về các yếu tố đã tác động đến việc sử dụng tri thức này được tìm hiểu thông qua những cuộc phỏng vấn sâu.

Kết quả nghiên cứu cho thấy các tộc người ở huyện Lạc Dương hiện nay vẫn kết hợp giữa việc chữa trị bệnh bằng phương pháp Tây $\mathrm{Y}$ (thuốc được cấp từ trạm xá hoặc bệnh viện) và phương pháp dân gian (sử dụng những loài động thực vật). Mặc dù, hiện nay các tộc người vẫn sử dụng các loài động thực vật trong chữa trị bệnh nhưng tỷ lệ này đã thay đổi do nhiều yếu tố tác động như quan niệm về bệnh tật, quan niệm về đặc tính và công dụng của các loài động thực vật và chính sách bảo vệ rừng.

\section{ABSTRACT}

The objectives of this paper are to explore issues relating to indigenous knowledge of using flora and fauna in healthcare and factors affecting their actual use among ethnic groups in Lac Duong district in the Lang Biang biosphere reserve's core area. 
Keywords:

ethnic minorities, indigenous knowledge, Lac Duong, plants and animals

The research was conducted quantitatively and qualitatively among 308 respondents in Lac Duong district. Data were collected using structured questionnaires and in-depth interviews. Structured questionnaires focus on the respondents' background and their knowledge of using plant and animal products for medicinal purposes. In-depth interviews, on the other hand, give an insight into factors affecting the use of such knowledge.

The results show that ethnic groups in Lac Duong district currently use both the Western sector (using medicine from the local health center or hospitals) and the Folk sector (using herbal and animal products) for the prevention and treatment of different diseases. However, the rate of using plants and animals as medicinal treatments has changed due to various factors such as changes in the public's beliefs about diseases, about characteristics and efficiency of using plant and animal treatments, and stricter forest protection policy.

\section{1. Đặt vấn đề}

Một số loài động thực vật được xem là có khả năng chữa trị một số căn bệnh trong các hệ thống y tế truyền thống trên khắp thế giới. Dường như nhiều bệnh được điều trị bằng động vật cũng được xử lý bằng cây (Alves \& Rosa, 2005). Hiện tượng này cho phép chúng tôi nêu lên các câu hỏi liên quan đến những lợi ích của việc sử dụng các loài động thực vật để chăm sóc sức khỏe và ngụ ý cho việc duy trì những thực hành y học truyền thống.

Tuy nhiên, trong những thập kỷ gần đây, các quá trình toàn cầu hóa và phát triển kinh tế tăng tốc không chỉ mang đển những điểm tích cực mà còn đã dẫn đến nhiều hậu quả chưa được khám phá. Một trong những vấn đề chính liên quan đến khuynh hướng này là khả năng đe dọa các nền văn hóa thiểu số và những yếu tố thúc đẩy những sự thay đổi trong việc sử dụng những kiến thức và thực hành truyền thống (Case, Pauli, \& Soejarto, 2005).

Do đó, những nỗ lực đã được thực hiện để đánh giá và đo lường những thay đổi này trong kiến thức truyền thống. Những nồ lực này chủ yếu tập trung vào kiến thức về sử dụng động thực vật vì đây là một thành phần quan trọng trong kiến thức sinh thái truyền thống và vì động thực vật là nguồn tài nguyên được sử dụng trong các khía cạnh khác nhau của cuộc sống hàng ngày ở các nền văn hóa khác nhau trên thế giới (Case et al., 2005).

Brodt (2001) nói rằng kiến thức về những loài động thực vật bản địa được kết nối với thực hành sống của một cá nhân trong bối cảnh văn hóa của họ, và nó được truyền miệng. Tuy nhiên, những yếu tố này là rất dễ bị tổn thương với các biến đổi kết quả từ quá trình toàn cầu hóa. Vì vậy, các nghiên cứu trong lĩnh vực tìm hiểu về các loài động thực vật của một vùng địa lý và tri thức bản địa về cách sử dụng những loài động thực vật này có thể góp phần xác định những tri thức bản địa về động thực vật được phát triển trong một nền văn hóa nhất định như thế nào (Eyssartier, Ladio, \& Lozada, 2008; Lozada, Ladio, \& Weigandt, 2006).

Tri thức bản địa là cách thức sử dụng những hiểu biết, kỹ năng và triết lý được phát triển bởi những xã hội trong quá trình lịch sử tương tác lâu dài với môi trường tự nhiên, trong đó bao gồm việc sử dụng những kiến thức và phương pháp sử dụng các loài động thực vật để phòng 
ngừa và điều trị bệnh tật (Le \& Nguyen, 2016; WHO, 1996). Theo ước tính của Tổ chức y tế Thế giới, hơn $80 \%$ người dân ở các nước đang phát triển sử dụng các loại thuốc dân gian cho việc chăm sóc sức khỏe ban đầu của họ (WHO, 2007). Ngày nay, các nhà hoạch định chính sách cũng bắt đầu chú ý đến vai trò quan trọng của tri thức bản địa trong quá trình phát triển công nhận vai trò của các loại cây thuốc và hệ thống y tế truyền thống trong chăm sóc sức khỏe (World Bank, 2001).

Việt Nam hiện nay cũng nằm trong bối cảnh này. Với đặc trưng về điều kiện tự nhiên, khu dự trữ sinh quyển Lang Biang ở Việt Nam được xem là nơi bảo tồn nhiều loại động thực vật có thể được dùng trong lĩnh vực chăm sóc sức khỏe. Tuy nhiên, các nghiên cứu hiện nay chủ yếu được tiếp cận dưới góc độ đa dạng sinh học, kết quả nghiên cứu thường tập trung xác định các loài động thực vật được sinh trưởng và bảo tồn như thế nào (Hoang, Lo, \& Pham, 2017). Hoặc một số công trình cũng bước đầu nghiên cứu về giá trị y học của các loài động thực vật (Le et al., 2014; Tran \& Dinh, 2014). Tuy nhiên, những nghiên cứu tìm hiểu về thực trạng sử dụng và cách thức lưu truyền những tri thức bản địa này dưới quan điểm của người dân vẫn chưa được công bố nhiều. Những nghiên cứu về các yếu tố kinh tế - văn hóa - xã hội tác động đến việc thực hành các tri thức bản địa trong chăm sóc sức khỏe vẫn chưa được tìm hiểu sâu rộng. Do đó, bài viết tập trung trình bày thực trạng sử dụng tri thức bản địa trong chăm sóc sức khỏe và các yếu tố tác động đến thực trạng sử dụng của các tộc người ở huyện Lạc Dương - nơi nằm trong vùng lõi của khu dự trữ sinh quyển Lang Biang. Từ đó, cho thấy vai trò của đơn nguyên y tế truyền thống đã biến đổi như thế nào trong bối cảnh phát triển hiện nay.

\section{Phương pháp nghiên cứu}

Nghiên cứu được thiết kế theo hướng định lượng và định tính. Các chủ đề nghiên cứu trong bảng khảo sát định lượng chủ yếu gồm những đặc trưng về nhân khẩu học, thực trạng sử dụng những loài động thực vật để làm thuốc và việc lưu truyền kiến thức bản địa về việc sử dụng những loại động thực vật này. Trong khi đó, các chủ đề trong dữ liệu định tính đi sâu vào việc tìm hiểu quan niệm của người dân về việc thực hành chữa trị bệnh tật bằng các loại động thực vật và sự biến đổi trong việc thực hành này dưới tác động của bối cảnh văn hóa-xã hội địa phương.

Toàn bộ dữ liệu được thu thập vào năm 2018 tại huyện Lạc Dương, tỉnh Lâm Đồng1 Tổng cộng có 1065 người tham gia vào cuộc nghiên cứu. Tuy nhiên, số lượng thông tín viên ở huyện Lạc Dương là 308 người theo định mức. Dựa theo định mức này, các thông tín viên được mời tham gia vào đề tài và chúng tôi tiến hành thu thập thông tin cho đến khi đủ định mức và thông tin được bão hòa. Trong đó số lượng nam là 222 người và nữ là 86 người. Cuộc khảo sát tiến hành ở 01 thị trấn và 5 xã của huyện Lạc Dương, nơi tập trung đông tộc người Cil, Cơ ho, Lạch. Các địa bàn khảo sát được lựa chọn theo tiêu chí: 1 địa bàn ở trung tâm huyện, 2 địa bàn ở xa trung tâm huyện và 3 địa bàn có hệ thống giao thông thuận lợi nằm trên trục đường chính nối tỉnh Khánh Hoà. Dữ liệu sau khi thu thập được tiến hành xử lý theo phần trăm và phân tích theo nhóm chủ đề.

Khu dự trữ sinh quyển Lang Biang (KDTSQ) được phân bố trên các địa bàn của tỉnh Lâm Đồng như huyện Lạc Dương, huyện Đam Rông, huyện Lâm Hà, huyện Đơn Dương, huyện

\footnotetext{
${ }^{1}$ Trích từ bộ dữ liệu đề tài cấp Đại học Quốc gia TP.HCM "Hoạt động kinh tế - văn hóa - xã hội của các tộc người thiểu số tại chỗ ở khu dự trữ sinh quyển Lang Biang theo định hướng phát triển bền vững", mã số đề tài B2018b18-03
} 
Đức Trọng và thành phố Đà Lạt với hệ sinh thái rừng đặc trưng và các hệ động thực vật. Theo số liệu thống kê từ Trung tâm Du lịch sinh thái và Giáo dục môi trường của Vườn quốc gia $\mathrm{Bi}$ Doup - Núi Bà, 748 loài động vật thuộc 507 giống, 123 họ, 6 lớp với 3 loài đặc hữu, 45 loài có tên trong Sách Đỏ Việt Nam (2007) trong đó có 19 loài có giá trị bảo tồn cao. Với sự đa dạng về các loại động thực vật, các tộc người ở khu vực Lang Biang đã xây dựng một nền tảng tri thức bản địa về chăm sóc sức khỏe.

\section{Kết quả nghiên cứu}

\section{1. Đặc điểm về nhân khẩu học}

Về địa bàn cư trú của các thông tín viên, nghiên cứu tiến hành ở 1 thị trấn và 5 xã trực thuộc huyện Lạc Dương gồm: thị trấn Lạc Dương, xã Dar Sar, xã Dar Nhim, xã Dar Chais, xã Lát và xã Đưng K'Nớ. Trong đó, hơn $1 / 3$ thông tín viên cư trú ở xã Lát nơi thuộc vùng lõi của khu dự trữ sinh quyển Lang Biang và có tộc người Cil sinh sống chủ yếu. Riêng đối với xã Đưng K'Nớ nơi được cho là cách trung tâm thị trấn Lạc Dương hơn $40 \mathrm{~km}$ với hệ thống đường giao thông chưa được bê tông hóa hoàn toàn nên khó khăn trong việc di chuyển, nhất là vào mùa mưa, số lượng thông tín viên tham gia trả lời chiếm khoảng 16\%. Trong khi đó, số lượng thông tín viên ở thị trấn Lạc Dương là $20.1 \%$, nơi đây là đơn vị hành chính trung tâm của huyện với đặc điểm đường giao thông thuận tiện và nhiều loại hình du lịch thu hút nhiều khách trong và ngoài nước đến tham quan (xem Bảng 1 ).

\section{Bảng 1}

Địa bàn cư trú của các thông tín viên

\begin{tabular}{|c|l|c|c|}
\hline Số TT & \multicolumn{1}{|c|}{ Địa bàn } & Số lượng (người) & Phần trăm (\%) \\
\hline 1 & Thị trấn Lạc Dương & 62 & 20.1 \\
\hline 2 & Xã Dar Sar & 35 & 11.4 \\
\hline 3 & Xã Dar Nhim & 28 & 9.1 \\
\hline 4 & Xã Dar Chais & 25 & 8.1 \\
\hline 5 & Xã Lát & 108 & 35.1 \\
\hline 6 & Xã Đưng K'Nớ & 50 & 16.2 \\
\hline & Tổng cộng & $\mathbf{3 0 8}$ & $\mathbf{1 0 0}$ \\
\hline
\end{tabular}

Nguồn: Kết quả phân tích dữ liệu của nhóm nghiên cứu

Trong tổng số 308 người tham gia khảo sát, số lượng tộc người Cil chiếm hơn $50 \%$. Sau đó là các tộc người Lạch, Cơ ho lần lượt chiếm hơn $10 \%$. Số lượng các tộc người khác M’nông, Tày, Chăm, Chu ru chiếm tỷ lệ không đáng kể. Liên quan đến loại hình tôn giáo, đa phần những thông tín viên là tín đồ của Công Giáo và Tin Lành với tỷ lệ lần lượt là $41.2 \%$ và $43.8 \%$. Số lượng thông tín viên theo 2 loại hình tôn giáo này chiếm hơn $80 \%$. Các tôn giáo còn lại như Phật giáo, Hòa Hảo chiếm khoảng 5\%. Ngoài ra, khoảng $10 \%$ thông tín tiên không tham gia bất kỳ loại hình tôn giáo nào. 
Về độ tuổi của những thông tín viên được chia làm 4 nhóm: thanh niên (từ 16 - 30 tuổi), trung niên (từ 31 đến 59 tuổi), người cao tuổi (từ 60 - 74 tuổi) và người già (từ 75 tuổi trở lên). Độ tuổi trung bình của các thông tín viên là 48 tuổi. Trong đó, nhóm trung niên chiếm đa số với $67 \%$. Nhóm người cao tuổi và người già khoảng $20 \%$. Tỷ lệ nhóm thanh niên tham gia trả lời là $13 \%$ (xem Hình 1).

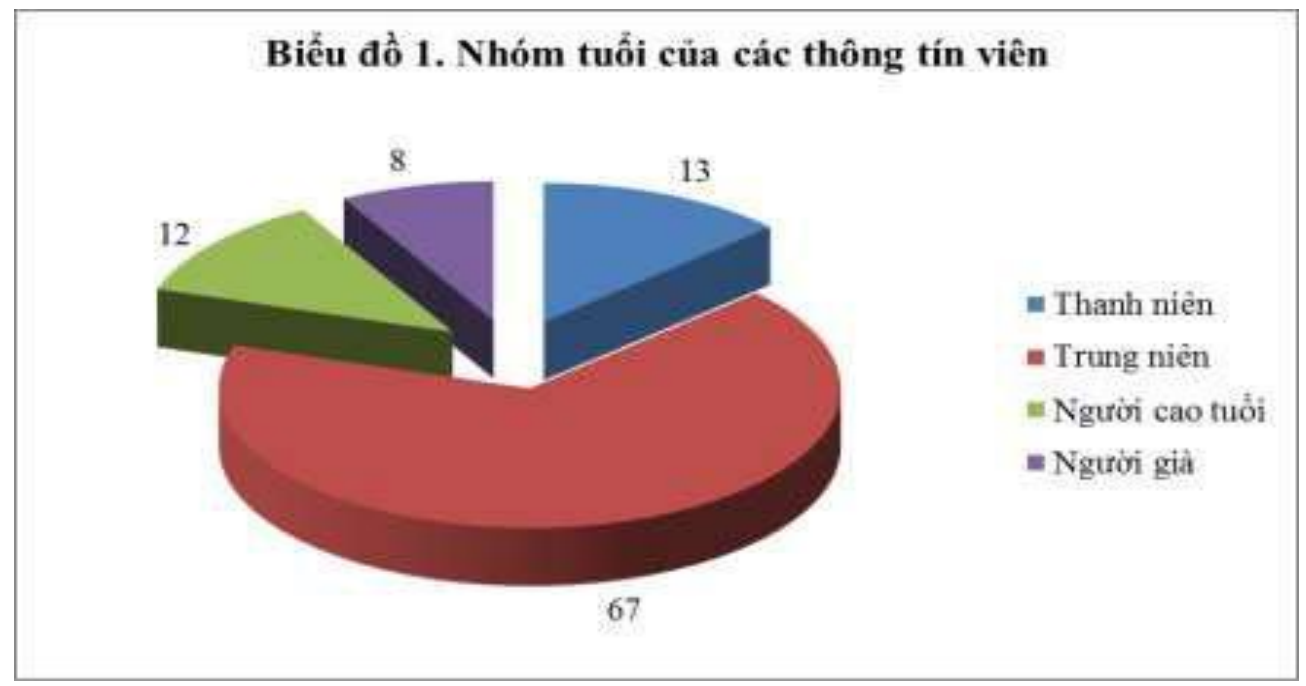

Hình 1. Nhóm tuổi của các thông tín viên

Về trình độ học vấn của thông tín viên, kết quả cho thấy tỷ lệ các tộc người thiểu số ở huyện Lạc Dương không biết đọc biết viết chiếm $14.6 \%$ trong tổng số. Tỷ lệ này bằng với tỷ lệ người chỉ biết đọc biết viết chưa hoàn thành bất kỳ cấp học nào. Trong khi đó, tổng số thông tín viên hoàn thành cấp 1 và cấp 2 lần lượt là $23 \%$ và $24.7 \%$ chiếm gần $1 \frac{1}{2}$ tổng số thông tín viên tham gia trả lời.

\section{Bảng 2}

Trình độ học vấn của các thông tín viên

\begin{tabular}{|l|c|c|}
\hline \multicolumn{1}{|c|}{ Giá trị } & Số lượng & Phần trăm \% \\
\hline Mù chữ & 45 & 14.6 \\
\hline Biết đọc biết viết & 44 & 14.3 \\
\hline Cấp 1 & 71 & 23.0 \\
\hline Cấp 2 & 76 & 24.7 \\
\hline Cấp 3 & 53 & 17.2 \\
\hline TC,CĐ,ĐH & 18 & 5.8 \\
\hline Trên Đại học & 01 & 0.4 \\
\hline Tổng cộng & 308 & 100.0 \\
\hline
\end{tabular}

Nguồn: Kết quả phân tích dữ liệu của nhóm nghiên cứu 
Liên quan đến nghề nghiệp của các thông tín viên, hầu hết thông tín viên làm nông như trồng café, hoa màu, các loại hoa... chiếm hơn $70.5 \%$. Tiếp đó là nhóm viên chức, buôn bán dịch vụ và làm thuê lần lượt là $6.5 \%, 5.8 \%$ và $4.9 \%$.

\section{Bảng 3}

Nghề nghiệp của các thông tín viên

\begin{tabular}{|l|c|c|}
\hline \multicolumn{1}{|c|}{ Giá trị } & Số lượng & Phần trăm \\
\hline Làm nông & 217 & 70.5 \\
Buôn bán & 18 & 5.8 \\
Nhân viên nhà nước & 20 & 6.5 \\
Làm thuê & 15 & 4.9 \\
Học sinh/ Sinh viên & 1 & .3 \\
Nội trợ & 7 & 2.3 \\
Thất nghiệp & 1 & .3 \\
Hưu trí & 10 & 3.2 \\
Mất sức & 16 & 5.2 \\
Công việc khác & 3 & 1.0 \\
Tổng cộng & 308 & 100.0 \\
\hline
\end{tabular}

Nguồn: Kết quả phân tích dữ liệu của nhóm nghiên cứu

\subsection{Thục trạng sử dụng nhũng loài động thục vật trong lĩnh vục chăm sóc sức khỏe}

Kết quả khảo sát cho thấy rằng số lượng thông tín viên biết một số loài động thực vật dùng để chữa bệnh chiếm hơn $2 / 3$ tổng số, với tỷ lệ $78.9 \%$. Trong số đó, có 239/243 người biết cách chế biến những loài động thực vật này thành những phương thuốc dùng để chữa trị một số loại bệnh.

Mặc dù các tộc người biết sử dụng các loài động thực vật để chữa trị bệnh chiếm tỷ lệ cao nhưng chỉ có $40 \%$ sô hộ gia đình có sử dụng các loại cây và động vật ở trong rừng. Trong đó, tỷ lệ hộ gia đình sử dụng động vật để làm thuốc chỉ chiếm $17.5 \%$ trong tổng số hộ. Riêng đối với các loại cây và nấm, số lượng hộ sử dụng dùng để bào chế thuốc là $51 \%$, gấp 3 lần so với việc dùng các loài động vật. Nguyên nhân của sự khác biệt này là do đa phần các loài động vật dùng để chữa bệnh như gấu và nhím ngày nay đã bị cấm săn bắt. Trong khi đó, các loài thực vật không chỉ được tìm thấy trong rừng mà còn có thể tìm thấy xung quanh nhà hoặc các tộc người có thể tự trồng. Khác với các loại thực vật, hầu hết việc chăm sóc sức khỏe sử dụng động vật ở trong rừng. Nhóm động vật được nuôi để làm thuốc không được tìm thấy trong kết quả nghiên cứu (xem Bảng 4). 


\section{Bảng 4}

Thực trạng sử dụng các loài động thực vật để chữa trị bệnh

\begin{tabular}{|c|c|c|c|}
\hline & $\begin{array}{c}\text { Gia đình có sử } \\
\text { dụng các con vật } \\
\text { trong rừng? }\end{array}$ & $\begin{array}{c}\text { Động vật trong } \\
\text { rùng dùng để làm } \\
\text { thuốc }\end{array}$ & $\begin{array}{c}\text { Thực vật dùng để } \\
\text { làm thuốc }\end{array}$ \\
\hline Có & 124 & 54 & 157 \\
\hline Không & 184 & 70 & 151 \\
\hline Tổng cộng & 308 & 124 & 308 \\
\hline
\end{tabular}

Nguồn: Kết quả phân tích dữ liệu của nhóm nghiên cứu

Kết quả khảo sát cũng đồng thời cho thấy việc bào chế các bài thuốc từ các loài động thực vật của các thông tín viên là do được ông/bà hoặc cha mẹ truyền lại, hoặc do học hỏi từ những người trong cộng đồng, hoặc do kinh nghiệm bản thân. Đây là ba nguồn tham khảo chủ yếu của các thông tín viên. Trong đó, việc học hỏi bào chế các bài thuốc từ sự truyền dạy của ông/bà hoặc cha mẹ trong gia đình chiếm hơn $50 \%$. Ngoài ra, việc học hỏi từ các cán bộ chuyên trách hoặc từ các tộc người khác chiếm tỷ lệ không đáng kể, khoảng 4\% (xem Hình 2).

\section{Biểu đồ 2. Nguồn tham khảo của việc chế biến các bài thuốc từ các loài động thực vật}
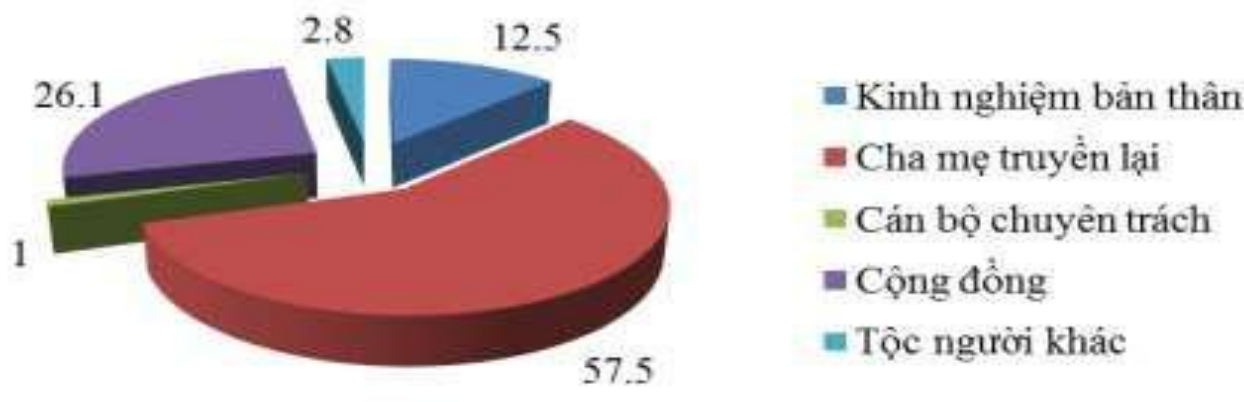

Hình 2. Nguồn tham khảo của việc chế biến các bài thuốc từ các loài động thực vật

Các tộc người ở trong khu vực Lang Biang thường không có kỹ thuật thu hái, chế biến hay nuôi trồng các loại động thực vật để làm thuốc. Trong cộng đồng người Cil có rất nhiều phương thuốc được chế biến từ những cây lấy trong rừng hay những cây mọc sau vườn và từ động vật. Họ thường đi lên rẫy và tiện đường hái về chứ không vào rừng sâu. Việc thu hái những lá cây hay săn bắt những động vật để làm phương thuốc chữa bệnh không được coi là một nghề trong cộng đồng, chỉ những ai biết và muốn sử dụng thì sẽ đi thu hái.

Hiện nay, các tộc người chỉ biết được một vài cây để trị được những bệnh thông thường hoặc sơ cứu. Nguyên nhân của việc hạn chế sử dụng các loại động thực vật để chữa trị đã được đề cập ở trên bao gồm yếu tố tôn giáo; sự phát triển của hệ thống y tế các cấp và việc cấm săn bắt thú rừng. 


\section{Bảng 5}

Một số thực vật chủ yếu được dùng để chữa trị các bệnh

\begin{tabular}{|c|c|c|c|c|}
\hline \multirow{2}{*}{ STT } & \multicolumn{2}{|c|}{ Tên cây thuốc } & \multirow{2}{*}{ Công dụng } & \multirow{2}{*}{ Kỹ thuật thu hái, chế biến } \\
\hline & Tiếng Việt & Tiếng dân tộc & & \\
\hline 1 & Cây mật gấu & Chi ma & $\begin{array}{l}\text { Trị đau bụng, } \\
\text { sốt }\end{array}$ & $\begin{array}{l}\text { Lá màu vàng, giống như các } \\
\text { loại cây cỏ, cao khoảng lên đầu } \\
\text { gối, có thể sử dụng thân, lá, rễ } \\
\text { để nấu }\end{array}$ \\
\hline 2 & Cây quý & Chi đon & $\begin{array}{l}\text { Xổ giun, sán, } \\
\text { trị sốt rét, } \\
\text { thanh nhiệt }\end{array}$ & $\begin{array}{l}\text { Cây thân gỗ, dùng thuốc thì lấy } \\
\text { vỏ hoặc lá, nấu lên uống hằng } \\
\text { ngày }\end{array}$ \\
\hline 3 & -2 & Trái Ple băh & $\begin{array}{l}\text { Chữa độc gắn } \\
\text { cắn }\end{array}$ & $\begin{array}{l}\text { Cây này chỉ có trong rừng, trái } \\
\text { như quả nhãn, vỏ đen bóng, } \\
\text { ruột trắng cứng, họ dây leo. } \\
\text { Chẻ đôi trái này ra, gắn lên } \\
\text { miệng vết thương, nó sẽ dính } \\
\text { luôn trên miệng vết thương. } \\
\text { Đến khi nó tự nhả ra thì có } \\
\text { nghĩa là đã hết độc. Sau đó áp } \\
\text { hai nửa lại, cất kín, khi dùng } \\
\text { thì chỉ cần cắt lớp mặt cũ đí }\end{array}$ \\
\hline 4 & Ót & - & $\begin{array}{l}\text { Xát thương } \\
\text { chó cắn }\end{array}$ & Cắt và chà lên vết thương \\
\hline 5 & Nấm mèo & - & $\begin{array}{l}\text { Chữa bệnh } \\
\text { tim, gan }\end{array}$ & Nấm mèo rừng nấu uống \\
\hline 6 & - & Nấm sa rit & $\begin{array}{l}\text { Tốt cho sức } \\
\text { khỏe. }\end{array}$ & $\begin{array}{l}\text { Mọc nhiều dưới đất trong rừng } \\
\text { già, có màu cam đặc trưng. Có } \\
\text { thể luộc, hoặc xào ăn với cơm }\end{array}$ \\
\hline 7 & - & Nấm sit katao & $\begin{array}{l}\text { Tốt cho sức } \\
\text { khỏe }\end{array}$ & $\begin{array}{l}\text { Màu trắng, mọc thành chùm, } \\
\text { mọc trong gốc cây, ít mọc chỗ } \\
\text { đất về luộc hoặc xào ăn }\end{array}$ \\
\hline 8 & - & $\begin{array}{l}\text { Lá ta prach mơ } \\
\text { nơm, rau nut, } \\
\text { rau má, bíp con } \\
\text { se }\end{array}$ & $\begin{array}{l}\text { Thanh nhiệt, } \\
\text { giải độc }\end{array}$ & $\begin{array}{l}\text { Mọc nhiếu trong rừng, hái luộc } \\
\text { hoặc nấu canh }\end{array}$ \\
\hline 9 & - & Cây nha prit & $\begin{array}{l}\text { Đau bụng, } \\
\text { tiêu chảy, } \\
\text { cầm máu. }\end{array}$ & Nhai sống. \\
\hline 10 & - & $\begin{array}{l}\text { Lá cây plai- } \\
\text { plah-kla }\end{array}$ & Chữa ho. & $\begin{array}{l}\text { Hái là rửa phơi khô, nấu nước } \\
\text { uống }\end{array}$ \\
\hline 11 & Nấm Linh chi & - & $\begin{array}{l}\text { Đau khớp, } \\
\text { đau đầu, gan, }\end{array}$ & Phơi khô nấu uống \\
\hline
\end{tabular}

\footnotetext{
${ }^{2}$ Không ghi nhận được tên gọi bằng tiếng Việt/tiếng dân tộc
} 


\begin{tabular}{|c|c|c|c|c|}
\hline \multirow{2}{*}{ STT } & \multicolumn{2}{|c|}{ Tên cây thuốc } & \multirow{2}{*}{ Công dụng } & \multirow{2}{*}{ Kỹ thuật thu hái, chế biến } \\
\hline & Tiếng Việt & Tiếng dân tộc & & \\
\hline & & & $\begin{array}{l}\text { nhứt mỏi } \\
\text { toàn thân. }\end{array}$ & \\
\hline 12 & Xả & Plăng & $\begin{array}{l}\text { Cảm cúm, } \\
\text { đau mắt }\end{array}$ & $\begin{array}{l}\text { Nấu nước uống cho bệnh cảm } \\
\text { cúm hoặc nấu rồi pha loãng } \\
\text { ngâm mặt vào chớp mắt để rửa } \\
\text { mắt }\end{array}$ \\
\hline 13 & Lá ổi & Pì tô & $\begin{array}{l}\text { Ho, cảm } \\
\text { cúm, đau } \\
\text { bụng. }\end{array}$ & $\begin{array}{l}\text { Nhai lá ối non hoặc nấu là phơi } \\
\text { khô uống }\end{array}$ \\
\hline 14 & $\begin{array}{l}\text { Thân cây } \\
\text { thông đỏ }\end{array}$ & - & $\begin{array}{l}\text { Đau lung, } \\
\text { nhứt mỏi } \\
\text { toàn thân. }\end{array}$ & $\begin{array}{l}\text { Đây là loại thông duy nhất } \\
\text { không có nhựa dùng để sắt } \\
\text { nhỏ, nấu nước uống }\end{array}$ \\
\hline 15 & Cây ngũ gia bì & Cây chi lộ & $\begin{array}{l}\text { Tốt cho sức } \\
\text { khỏe }\end{array}$ & $\begin{array}{l}\text { Có thể dùng cả thân, lá, rễ, gai } \\
\text { để nấu uống như trà, vị hơi } \\
\text { đắng }\end{array}$ \\
\hline 16 & Sâm rừng & - & Đau lung & $\begin{array}{l}\text { Phơi khô nấu uống hoặc nấu } \\
\text { làm thức ăn }\end{array}$ \\
\hline 17 & - & Hạt ple plah kla & Chữa ho & Phơi khô nấu uống \\
\hline 18 & Quả thơm rừng & $\begin{array}{l}\text { Ple sơ ko mơ } \\
\text { nơm }\end{array}$ & $\begin{array}{l}\text { Đau mỏi, } \\
\text { nhứt người. }\end{array}$ & Thái nấu nước uống \\
\hline 20 & Gạo & - & Chó cắn & $\begin{array}{l}\text { Nhai nát gạo sống phun lên vết } \\
\text { thương }\end{array}$ \\
\hline 21 & Cà & - & $\begin{array}{l}\text { Tiểu đường, } \\
\text { huyết áp }\end{array}$ & $\begin{array}{l}\text { Được hái trên rừng già, phơi } \\
\text { khô nấu uống như trà }\end{array}$ \\
\hline 22 & Hoa trà & - & Gout & $\begin{array}{l}\text { Thường mọc ven đường hay } \\
\text { trên rừng, bông trắng, phơi khô } \\
\text { cả cây nấu uống như trà }\end{array}$ \\
\hline 23 & Rau rừng đắng & $\begin{array}{l}\text { Pai he vi si ma } \\
\text { tum }\end{array}$ & Đau đầu & $\begin{array}{l}\text { Lấy nguyên cây nấu lấy nước } \\
\text { uống }\end{array}$ \\
\hline 24 & - & Pai sa pi & Hồi sức & Giã với muối, ăn với gạo \\
\hline 25 & Ngãi & - & $\begin{array}{l}\text { Đau bụng, } \\
\text { mát người }\end{array}$ & \\
\hline 26 & Đọt tỏi & - & Chữa ho & Nhai sống \\
\hline 27 & $\begin{array}{l}\text { Nõn thông } \\
\text { (thông không } \\
\text { nhựa) }\end{array}$ & - & Chữa ho & Nấu nước uống \\
\hline 28 & Rễ chanh & - & Trị sốt & Nấu nước uống hoặc tắm \\
\hline
\end{tabular}

Nguồn: Kết quả phân tích dữ liệu của nhóm nghiên cứu 


\section{Bảng 6}

Một số động vật dùng để chữa trị các bệnh phổ biến

\begin{tabular}{|c|c|c|c|c|}
\hline \multirow[b]{2}{*}{ STT } & \multicolumn{2}{|c|}{ Tên động vật } & \multirow[b]{2}{*}{ Công dụng } & \multirow[b]{2}{*}{$\begin{array}{c}\text { Kỹ thuật thu hái, chế } \\
\text { biến }\end{array}$} \\
\hline & $\begin{array}{l}\text { Tiếng địa } \\
\text { phương }\end{array}$ & $\begin{array}{c}\text { Tiếng đồng } \\
\text { bào }\end{array}$ & & \\
\hline 1 & Sóc & Brố & Tốt cho sức khỏe & $\begin{array}{l}\text { Dùng rổ bẫy sóc, làm sạch } \\
\text { lông, lấy huyết tươi và mật } \\
\text { sóc ngâm rượu. Thịt được } \\
\text { dùng làm thức ăn. }\end{array}$ \\
\hline 2 & Nhím & - & Đau bao tử & $\begin{array}{l}\text { Làm sạch, lấy da mang } \\
\text { bán, thịt dùng làm thức ăn, } \\
\text { bao tứ nhím phơi khô nâu } \\
\text { uống chữa đau bao tử. }\end{array}$ \\
\hline 3 & Tê tê & - & Đau khớp, đau cơ & $\begin{array}{l}\text { Tê tê dùng để làm thuốc, } \\
\text { vỏ tê tê rất đắt ( } 20.000 \\
\text { đồng/1 lạng), con lớn } \\
\text { khoảng } 3 \mathrm{~kg} \text {, con nhỏ } \\
\text { khoảng } 1 \mathrm{~kg} \text {. Thịt được } \\
\text { dùng làm thức ăn. }\end{array}$ \\
\hline 4 & Gấu & - & $\begin{array}{l}\text { Thuốc thoa vết } \\
\text { sưng hoặc uống }\end{array}$ & $\begin{array}{l}\text { Lấy mật ngâm với rượu } \\
\text { chữa cấc bệnh như gãy } \\
\text { chân, gãy tay... nếu sưng } \\
\text { khớp thì lấy mật thoa lên } \\
\text { chỗ bị sưng. }\end{array}$ \\
\hline 5 & Khỉ & - & Động kinh & $\begin{array}{l}\text { Lấy óc khỉ hấp chín ăn trị } \\
\text { động kinh. Thịt được dùng } \\
\text { làm thức ăn. }\end{array}$ \\
\hline
\end{tabular}

Nguồn: Kết quả phân tích dữ liệu của nhóm nghiên cứu

\section{vật}

\section{Các yếu tố tác động đến việc thực hành chữa trị bệnh bằng các loại động thực}

Kết quả nghiên cứu cho thấy rằng mặc dù việc thực hành chữa trị bệnh bằng tri thức dân gian vẫn tồn tại trong cộng đồng, tuy nhiên số lượng người sử dụng phương thức này chiếm dưới $50 \%$ trong tổng số người tham gia trả lời. Thay vào đó, các tộc người ở huyện Lạc Dương lựa chọn các cơ sở y tế như trạm xá, bệnh viện để điều trị các bệnh tật. Nguyên nhân của việc này là do sự thay đồi về quan niệm bệnh tật, hay quan niệm về đặc tính và công dụng của các loại thuốc và chính sách bảo vệ rừng.

\subsection{Quan niệm về bệnh tật}

Dựa theo kết quả phỏng vấn sâu, quan niệm về bệnh tật của các thông tín viên đã có sự thay đổi so với trước đây. Một vài thông tín viên cho rằng, trước khi đạo Tin Lành và Công giáo du nhập vào địa phương, các tộc người ở đây đều quan niệm bệnh tật là do thần linh, ma quỷ gây nên. Vì vậy muốn khỏi bệnh thì họ phải giết heo, gà rồi nhờ thầy cúng đến cúng. Tuy nhiên, từ khi các tộc người ở đây sinh hoạt đạo Tin Lành và Công giáo thì họ chỉ tin vào Chúa 
và cho rằng thần linh, ma quỷ là không có thật. Do đó, việc thực hành chữa trị của các tộc người thiểu số ở huyện Lạc Dương đa phần được tiến hành tại các trạm xá và bệnh viện.

Ngoài ra, theo quan niệm của các thông tín viên, ngày nay bệnh tật là do sự thay đổi của thời tiết, ăn uống không hợp vệ sinh hoặc do nhiễm vi khuẩn, vi rút. Những quan niệm này do quá trình tiếp cận các thông tin truyền thông về sức khỏe từ trạm y tế, y tế thôn bản và những buổi sinh hoạt tại các cơ sở tôn giáo mà các tộc người ở huyện Lạc Dương nhận được. Từ quan niệm này, hành vi chữa trị bệnh tật của họ cũng thay đổi. Họ thường đến các trạm xá để khám bệnh và mua thuốc tây về uống.

Tuy nhiên, theo chia sẻ của một thông tín viên người Lạch ở thị trấn Lạc Dương, mặc dù hiện nay các tộc người xung quanh cũng như gia đình của thông tín viên thường sử dụng thuốc tây để chữa bệnh nhưng ông bà, cha mẹ của thông tín viên vẫn truyền dạy một số bài thuốc đơn giản để áp dụng trong cuộc sống hằng ngày. Những chia sẻ tương tự về vấn đề này cũng tìm thấy ở các thông tín viên tại xã Dar Chais:

"Bên cạnh việc chũa trị bằng thẻ bảo hiểm y tế ở trạm xá, ho còn có ý cho rằng: nhiều lúc thuốc ở trạm y tế không khỏi nên họ dùng các cây thuốc mà người dân chỉ cho đôi khi cũng bớt bệnh, chắc do hợp với cây đó."

Theo ý kiến chia sẻ của nhiều thông tín viên, mặc dù sự tiện lợi của hệ thống y tế hiện đại phát triển nhưng các tộc người ở huyện Lạc Dương vẫn còn thực hành chữa trị bệnh tật bằng các loài động thực vật đối với những căn bệnh nhẹ như cảm, ho, sốt. Chẳng hạn như chia sẻ của thông tín viên ở Dar Chais:

“Thông thuờng khi gặp các biểu hiện bệnh giống nhu các bệnh thuờng gặp thì nguời dân sẽ tự chũa trị bằng các bài thuốc dân gian. Ho chủ yếu dựa vào kinh nghiệm truyền lại của nhũ̃ng thế hệ trước trong gia đình mà không qua truờng lớp đào tạo nào. Nếu tụ chũa không hiệu quả thì ho sẽ đến trạm y tế để được điều trị."

Từ chia sẻ này chúng ta có thể thấy rằng, các tộc người ở đây có một sự phân loại ban đầu về bệnh tật để lựa chọn phương thức điều trị phù hợp. Theo quan niệm của họ, bệnh tật được chia làm hai loại: bệnh nhẹ và bệnh nặng. Bệnh nhẹ là các căn bệnh cảm, ho, sốt, nhức đầu và có thể nhanh khỏi trong một vài ngày. Trong khi đó, bệnh nặng là những bệnh khó chữa khỏi hoặc thời gian để phục hồi lâu hơn.

Như vậy yếu tố quan niệm về nguyên nhân gây ra bệnh tật đã tác động đến việc thực hành chữa trị của các tộc người. Điển hình như sự thay đổi từ yếu tố thần linh, ma quỷ sang yếu tố về vi khuẩn hoặc sự rối loạn các chức năng trong cơ thể đã ảnh hưởng đến việc thực hành chữa trị của họ. Sự thay đổi này do quá trình tiếp cận các thông tin truyền thông về sức khỏe từ trạm xá hoặc các cơ sở sinh hoạt tôn giáo, và do sự phát triển và cải thiện chất lượng dịch vụ của hệ thống y tế từ cấp xã trở lên. Đặc biệt việc sở hữu thẻ bảo hiểm y tế cũng góp phần gia tăng sự lựa chọn trong chăm sóc sức khỏe tại các cơ sở y tế.

\subsection{Quan niệm về đặc tính và công dụng của các bài thuốc được bào chế tù̀ nhũng loài động thục vật}

Đặc tính của các loại động thực vật làm thuốc có nguồn gốc tự nhiên có tính tiện lợi vì một số loại thuốc có thể tìm kiếm ngay quanh nhà khi cần như lá ổi non, quả sung... khi cần là có thể tìm thấy và sử dụng ngay. Cách sử dụng thì cũng khá đơn giản chủ yếu là nấu lên rồi uống hoặc ăn sống. Giá cả lại rất rẻ hoặc thậm chí chỉ cần tìm kiếm trong tự nhiên hoặc quanh nhà. 
Bên cạnh đó, một số thông tín viên khác cho rằng thuốc tây hay các bài thuốc dân gian sử dụng các loài động thực vật đều có công dụng như nhau. Việc phân loại đặc tính thuốc thì hầu như các tộc người ở đây không thể phân biệt. Theo lời chia sẻ của một thông tín viên ở xã Lát:

"Ở đây không ai có quan niệm gì về đặc tính của thuốc, thấy loại nào sủ dụng hiệu quả thì bà con sẽ dùng tiếp, loại nào không có tác dụng thì sẽ không dùng nũ̃a. Cây thuốc nào chũa được bệnh thì là thuốc tốt, cây nào không thì là thuốc không tốt. Cây thuốc nào biết, thấy, lúc cần thì hái về sử dụng."

Tuy nhiên, nhiều thông tín viên khác cho rằng các bài thuốc trị bệnh hầu hết đều đã thất truyền. Đa phần các bài thuốc tự bào chế do ông bà ngày xưa thực hiện nhưng không truyền lại cho con cháu. Do đó, các tộc người ở đây dần quên các công thức điều chế các bài thuốc này. Ngoài ra, thuốc dân gian được bào chế từ những cây cỏ trong rừng đòi hỏi người sử dụng phải biết cách chế biến và trải qua nhiều công đoạn. Do đó, việc dùng thuốc dân gian vừa tốn thời gian vừa tốn công sức. Đặc biệt, đối với một vài thông tín viên cho rằng bản thân họ không biết rõ các phương thuốc, cây thuốc ở trong rừng dùng để chữa bệnh nên họ không dám sử dụng. Điển hình chia sẻ của một thông tín viên ở xã Dar Chais:

"Nhu đã nói ở trên, người dân ở đây bây giờ tin dùng vào y học hiện đại hơn là y học dân gian, y học cổ truyền. Điều này được chưng minh qua việc dù chỉ là bệnh nhẹ ho cũng lên trạm xá để xin thuốc, nếu không thì sẽ lên trên huyện hoặc tỉnh để khám và điều trị. Đối với họ, họ nghĩ rằng bản thân không còn biết rõ các phuơng thuốc, cũng nhu nguồn gốc và công dụng của các cây thuốc ở trong rùng nũa nên không dám sủ dụng bưa bãi. "”

Mặc dù vậy, theo chia sẻ của một số thông tín viên ở xã Đưng K'Nớ cho rằng nếu chữa trị bệnh bằng các loại động thực vật sẽ không đạt được hiệu quả nhanh chóng mà phải mất một khoảng thời gian. Do đó, người sử dụng thuốc phải có sự kiên trì. Ngoài ra, dùng các bài thuốc được bào chế bằng hình thức này sẽ không ảnh hưởng nhiều đến cơ thể của người bệnh.

"Nhìn chung mỗi loại thuốc đều có nhũng tác dụng riêng của nó. Thuốc nam [thuốc được bào chế tù những loại động thực vật] it độc, an toàn nhưng thời gian sủ dụng lâu dài."

"Bây giờ uống thuốc ở y tế nhiều không tốt bằng mấy cái lá thuốc đâu. Tuy lá thuốc nó lâu khỏi hơn nhưng nó tốt hơn. Nó không nóng đâu, còn thuốc ở y tế nó nóng nhưng nó nhanh hết."

\subsection{Chính sách bảo vệ rùng}

Theo kết quả phỏng vấn sâu, nhiều thông tín viên chia sẻ rằng hiện nay do đề án bảo vệ và phát triển lâm nghiệp tỉnh Lâm Đồng, cụ thể là chương trình bảo vệ rừng của Nhà nước và chương trình chi trả dịch vụ môi trường rừng nên các tộc người ở đây không còn nhiều cơ hội để vào rừng thu lượm một số loài động thực vật có khả năng chữa trị bệnh. Do đó, ngày càng ít các bài thuốc được sử dụng trong cộng đồng. Thay vào đó, các tộc người tìm đến các cơ sở $\mathrm{y}$ tế để chữa trị các bệnh tật. Như chia sẻ của nhiều thông tín viên ở xã Dar Chais:

"Ví dụ nhu có một loài cây dùng để trị sốt rét nhung nó ở tận trong rùng. Giờ nhà nước đâu có cho đi vào rù̀ng nũa, nên giờ cũng không còn ai biết cái cây đó nhu thế nào, chỉ có mấy ông già làng lớn tuổi thì có thể biết, chứ mấy ông già làng trẻ trẻ nhu bây giờ thì cunng không rành nhũng loại cây này đâu." 


\section{Kết luận}

Dựa theo kết quả nghiên cứu, các tộc người ở huyện Lạc Dương hiện nay vẫn kết hợp giữa việc chữa trị bệnh bằng hệ thống y tế và các loài động thực vật. Tuy nhiên bài viết bị hạn chế về số liệu thống kê tình hình sử dụng y học hiện đại và y học dân gian. Do đó, trong các nghiên cứu sau có thể bổ sung các số liệu này. Ngoài ra, kết quả nghiên cứu cũng cho thấy mặc dù hiện nay các tộc người vẫn sử dụng các loài động thực vật trong chữa trị bệnh nhưng tỷ lệ này đã thay đổi do nhiều yếu tố tác động như quan niệm về bệnh tật, quan niệm về đặc tính và công dụng của các loài động thực vật và chính sách bảo vệ rừng. Số lượng người biết cách bào chế các bài thuốc để chữa trị bệnh chủ yếu tập trung ở độ tuổi trung niên trở lên. Ngoài ra, đa phần nhóm này học hỏi từ kinh nghiệm của những ông bà và cha mẹ. Liên quan đến yếu tố quan niệm về bệnh tật, bài viết cũng nêu lên hai nguyên nhân cơ bản đã tác động đến sự thay đổi này đó là sự xuất hiện của tôn giáo và sự cải thiện về chất lượng dịch vụ của hệ thống y tế. Chính sự thay đổi này đã tác động đến sự thay đổi về quan niệm, từ đó thay đổi hành vi lựa chọn phương thức chữa trị bệnh của các tộc người thiểu số ở huyện Lạc Dương. Bài viết đồng thời cũng góp phần vào dữ liệu chứng minh sự kết hợp kiến thức và thực hành của ba đơn nguyên y tế gồm: $\mathrm{y}$ học hiện đại, $\mathrm{y}$ học dân gian và $\mathrm{y}$ học thường thức.

\section{Tài liệu tham khảo}

Alves, R. R. N., \& Rosa, I. L. (2005). Why study the use of animal products in traditional medicines? Journal Ethnobiology Ethnomedicine, 1, 1-5.

Brodt, S. B. (2001). A systems perspective on the conservation and erosion of indigenous agricultural knowledge in Central India. Human Ecology, 29, 99-120.

Case, R. J., Pauli, G., \& Soejarto, D. (2005). Factors in maintaining indigenous knowledge among ethnic communities of Manus Island. Economic Botany, 59, 356-365.

Eyssartier, C., Ladio, A. H., \& Lozada, M. (2008). Transmission of traditional ecological knowledge in two populations of North-Western Patagonia. Journal of Ethnobiology Ethnomedicine, 4(1), 25.

Hoang, H. T. T., Lo, B. T., \& Pham, K. N. (2017). Đa dạng thành phần loài và giá trị sủ dụng cây thuốc tại xã Púng Bánh, huyện Sốp Cộp, tỉnh Sơn La [Diversity of species composition and value of medicinal plants use in Pung Banh commune, Sop Cop district, Son La province]. Paper presented at Hội nghị Khoa học toàn quốc về sinh thái và tài nguyên sinh vật lần thứ 7, Hanoi, Vietnam.

Le, H. T. T., \& Nguyen, T. T. (2016). Nghiên cứu tri thức và kinh nghiệm sử dụng cây thuốc của các dân tộc thiểu số ở tỉnh Thái Nguyên để bảo tồn và phát triển bền vững [Research on knowledge and experience in using medicinal plants of ethnic minorities in Thai Nguyen province for conservation and sustainable development]. Tap chí Khoa hoc Tu nhiên và Công nghẹ, 32(1), 55-64.

Le, H. T. T., Ngo, P. D., Hoang, T. T., Dinh, A. T., Nguyen, T. T., \& Nguyen, T. N. (2014). Điều tra cây thuốc và giá trị sử dụng theo kinh nghiệm của đồng bào dân tộc Sán Dìu ở tỉnh Thái Nguyên [Investigation of medicinal plants and their use value according to the experience of the San Diu ethnic minority in Thai Nguyen province]. Tap chí Khoa hoc Tụ nhiên và Công nghệ, 30(3), 7-16. 
Lozada, M., Ladio, A. H., \& Weigandt, M. (2006). Cultural transmission of ethnobotanical knowledge in a rural community of northwestern Patagonia. Journal of Economic Botany, 60(4), 374-385.

Tran, T. H., \& Dinh, T. L. G. (2014). Thực trạng và giá trị sử dụng nguồn cây dược liệu tại xã Quy Hóa, huyện Minh Hóa, tỉnh Quảng Bình [Current situation and value of using medicinal plants in Quy Hoa commune, Minh Hoa district, Quang Binh province]. Tạp chí Thông tin Khoa học và Công nghệ Quảng Bình, 5, 50-54.

World Bank. (2001). Ethiopia-traditional medicine and the bridge to better health. Retrieved December 15, 2018, from: http://www.openknowledge.worldbank.org/handle/10986/10803

World Health Organization (WHO). (1996). Anonymous, traditional medicine. Retrieved December 16, 2018, from http://apps.who.int/gb/ebwha/pdf_files/EB134/B134_24en.pdf

World Health Organisation (WHO). (2007). The health of indigenous peoples. Retrieved December 17, 2018, from https://www.who.int/gender-equityrights/knowledge/factsheet-indigenous-healthn-nov2007-eng.pdf?ua=1 